\title{
Decoronation of ankylosed incisors in two adolescent patients
}

\author{
İki genç hastada ankiloze kesici dişlerin dekoranasyonu
}

Sevgin İBİ̧̧ ${ }^{1}$, Hatice AÇIKEL ${ }^{2}$, Emine ŞEN TUNÇ³

\begin{abstract}
Avulsion of permanent dentition represents a serious if relatively uncommon type of traumatic injury. The most frequent complication after replantation of teeth is ankylosis, from initial root resorption through eventual replacement of lost root substance with bone. Decoronation may be considered an alternative treatment strategy for ankylosed incisors in young patients. In the two cases reported on here, ankylosed teeth in adolescent patients were decoronated and prosthetically restored after late and less-than-ideal replantation procedures. The results obtained in these two cases are indications that decoronation may be a good treatment option for teeth affected by replacement and external resorption in young people who have not yet completed their growth and development.
\end{abstract}

Keywords: ankylosis, decoronation, dental trauma.

Sevgin İbiş $(\bowtie)$

${ }^{I}$ Specialist dentist, Bafra Dental Health Center, Samsun, Turkey

e-mail: sevginibis48@gmail.com

Hatice Açıkel

${ }^{2}$ Professor, Department of Pediatric Dentistry, Faculty of Dentistry,

Ondokuz Mayls University, Samsun, Turkey.

Emine Şen Tunç

3 Professor, Department of Pediatric Dentistry, Faculty of Dentistry, Ondokuz Mayls University, Samsun, Turkey.

Tel: 03625432472-112

Submitted / Gönderilme: 13.11.2018

Accepted/Kabul: 21.12.2018
Öz

Daimi dişlenmede avulsiyon oldukça nadir görülmekle birlikte, ciddi travmatik yaralanmalardandır. Başlangıç kök rezorbsiyonu sonrası kök dokularının zamanla kemik ile yer değiştirmesi şeklinde gözlenen ankiloz, reimplante edilen dişlerde en sık karşılaşılan komplikasyondur. Genç erişkin hastaların ankiloze kesici dişlerinin dekoranasyonu alternatif tedavi seçeneklerindendir. $\mathrm{Bu}$ olgu raporunda; geç ve uygun olmayan reimplatasyona bağlı ankiloz gelişen kesici dişlerin dekoranasyonu ve protetik tedavisi sunulmaktadır. Büyüme ve gelişimi henüz tamamlanmamış genç hastaların yer değiştirme ve dışsal rezorbsiyon gözlenen dişlerinin tedavisinde dekoronasyonun iyi bir tedavi seçeneği olabileceği sonucuna varılmıştır.

Anahtar Kelimeler: ankiloz, dekoronasyon, diş travmaları.

\section{Introduction}

Avulsion is a type of severe traumatic dental injury that accounts for $0,5-3 \%$ of all traumatic injuries to permanent dentition (1). Not only is the affected tooth completely displaced from its socket, the trauma causes injury to apical pulp, periodontal tissue and supporting bone and cement $(2,3)$ and may result in pulpal necrosis, root resorption and tooth $\operatorname{loss}(1-4)$.

Healing of an avulsion injury is a very complex process that is affected by numerous factors, including patient age, duration and medium of extraoral storage, and replantation management(1-5). Ankylosis-related replacement resorption is frequently observed after avulsion of permanent incisors (2), and Donaldson and Kinirons found that teeth left in dry conditions for longer than $15 \mathrm{~min}$ or whose roots suffered from additional damage or contamination faced higher risks of early resorption (6). Complications following ankylosis of a permanent incisor in children include early loss of the traumatised tooth, local arrest of alveolar-bone development, tilting of adjacent teeth, arch length loss, orthodontic 
complications related to arch irregularities, and poor aesthetics $(2,7)$. For these reasons, extraction of ankylosed or heavily resorbed young permanent teeth is not recommended (8). Alternative treatment options include autotransplantation of the tooth with a viable periodontal ligament, orthodontic closure, and decoronation $(1,8,9)$. The later treatment option preserves the labial contours of the socket and improves conditions for implant insertion in the future $(7,10)$.

The following report presents two cases of decoronation and prosthetic rehabilitation of teeth ankylosed due to late and less-than-ideal replantation procedures.

\section{Case reports}

\section{Case 1}

A healthy, 10-year-old girl was referred to the Ondokuz May1s University Faculty of Dentistry's Department of Pediatric Dentistry the day after a bicycle accident resulting in a traumatic avulsion injury to the maxillary right central incisor tooth, which was treated by replantation at another dental clinic. Extraoral examination showed no injuries, whereas intraoral examination revealed that the tooth had not been fully inserted into the socket and no splint had been applied. Radiographic examination confirmed that the tooth was incorrectly positioned and had an open apex (Figure 1). Under local anaesthesia (Ultracain DS Forte, Sanofi Aventis, Luleburgaz, Turkey), gentle finger pressure was used to guide the tooth into its original place, and a wire splint was applied using composite resin. A control radiograph was taken, the patient was prescribed a 10-day course of antibiotics along with analgesics and mouth rinse (Chlorhexidine gluconate $0.12 \%$ ), and tetanus vaccination status was ascertained. The patient and her parents were also given instructions regarding diet and about the importance of chemical and mechanical plaque control. The splint was removed after 2 weeks, but no further treatment was undertaken in order to allow for possible revascularization of the pulp space. Follow-up visits were scheduled for 1, 3, 6 and 12 months and annually thereafter. No clinical or radiographic pathology was observed at 1 or 3 months, after which time the patient discontinued follow-up. However, the patient presented 2 years later with an unrelated problem, and while intraoral examination showed no abnormalities, radiographic examination revealed replacement and external root resorption (Figure 2). The patient and her parents were informed about the likelihood of progressive root resorption and eventual tooth loss, and monthly follow-up appointments were scheduled. After 3 months, the patient reported pain during chewing in her maxillary right central incisor, and radiographic examination revealed continuing external root resorption (Figure 3). After informing the parents about the current clinical situation and treatment options, the decision was made to decoronate the tooth. Local anaesthesia (Ultracain DS Forte, Sanofi Aventis, Luleburgaz, Turkey) was administered, a full buccal and palatal mucoperiosteal flap was lifted, and the maxillary right central incisor was decoronated. The root canal was rinsed with saline, bleeding from the surrounding tissue was allowed to fill the canal (Figure 4a), and following clotting, an incision was made in the periosteum to enable wound-edge approximation without tension. The flap was primarily closed with 4-0 vicryl sutures using a horizontal mattress suturing technique, and the crown of the decoronated tooth was stored in saline solution in anticipation of soft-tissue healing. A post-operative radiograph was taken (Figure 4b), and the patient was prescribed antibiotics the (amoxicillin $500 \mathrm{mg}$ tid), analgesics ibuprofen $400 \mathrm{mg}$ tid) and chlorhexidine mouthwash for 5 days. After 15 days, the tooth crown was removed from storage, sectioned horizontally at the cementoenamel junction using a diamond abrasive disc, and contoured using a flame-shaped bur. Pulp remains were then removed with a bur, the pulp chamber was etched with $37 \%$ phosphoric acid, and the tooth was washed with air-blow and lightly air-dried. A bonding agent (Clearfil SE Bond, Kuraray, Okayama, Japan) was applied to the etched surface, and the access opening was sealed with light-curing resin composite (Gradia Direct Anterior, GC Corporation, Tokyo, Japonya). A fixed appliance was constructed using the natural crown, which was adapted using 0.9-mm round orthodontic wire and supported by the permanent first molar teeth. Following satisfactory try-in and occlusal adjustments, the appliance was cemented in place using glass ionomer cement at the same appointment (Figure 4c).

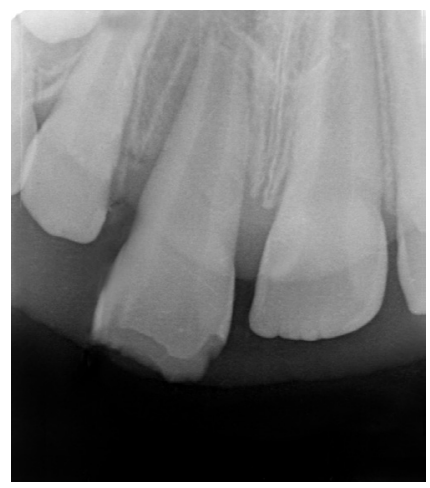

Figure 1: Initial periapical radiograph of avulsed tooth which replanted by a general dentist.

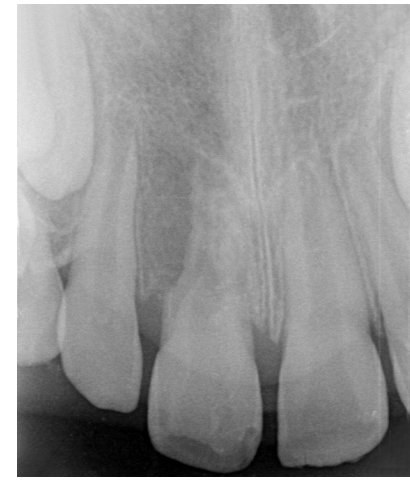

Figure 2: The radiographic view of Case 1 shows external root resorption and ankylosis after 2 years. 


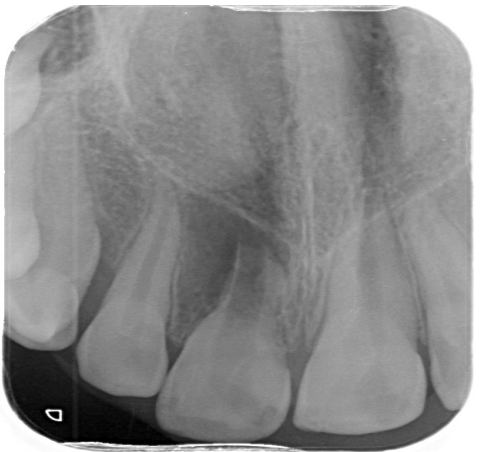

Figure 3: Radiographic view shows progressive root resorption in Case 1.

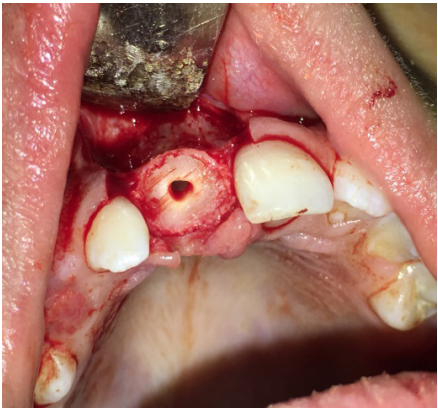

Figure 4a: Operation view

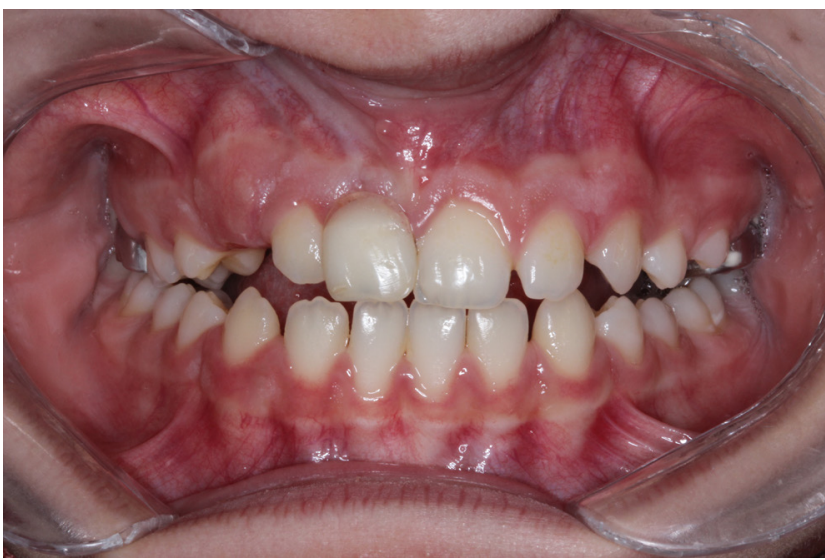

Figure 4c: Prosthetic rehabilition of Case 1

\section{Case 2}

An 11-year-old female patient was referred to the Ondokuz Mayıs University Faculty of Dentistry's Department of Pediatric Dentistry the day after an avulsion injury to the maxillary right central incisor caused by a fall at a playground, after which the tooth was stored in milk and replanted by a general practitioner 2 hours later. A medical history was non-contributory, physical and neurological assessments showed no specific findings, and no injuries were detected at extraoral examination. A clinical examination showed a less-than-ideal rigid composite splint on the injured tooth and adjacent teeth; however, radiographic examination showed that the tooth was positioned correctly and its apex was closed (Figure 5). The rigid composite splint was removed, and the traumatized tooth was resplinted with an acid-etched composite resin for one week. The patient was also given oral hygiene instruction and referred to a physician for evaluation of tetanus vaccination status. Endodontic treatment of the maxillary right central incisor was initiated 2 days after splint construction. The canal was instrumented and irrigated with normal saline and 2\% sodium hypochlorite solutions. Calcium hydroxide (3M Espe, St Paul, MN, ABD) was used as a temporary intracanal medicament, and permanent endodontic treatment was completed 15 days later (Sealapex Kerr Italia S.R.L. Via Passanti, Salerno-Italia). The tooth was then restored with composite resin (Gradia Direct Anterior, GC Corporation, Tokyo, Japonya), and follow-up visits were scheduled for clinical and radiographic evaluation of the roothealing process. At the 6-month follow-up visit, the replanted tooth showed signs of ankylosis on percussion. The patient and her parents were informed about the prognosis, and it was decided to continue with follow-up throughout the patient's growth and developmental period. At the 1-year follow-up visit, when the patient was 12 years of age, radiographic examination showed severe replacement and inflammatory cervical root resorption of the maxillary right lateral incisor along with pulp canal obliteration (Figure 6), but the tooth was clinically asymptomatic and provided good aesthetics. However, approximately 30 months later, when the patient was almost 15 years old, she sustained another traumatic dental injury, at which time clinical examination showed a fistula and mobility of the maxillary right central incisor, and a periapical radiograph revealed a horizontal root fracture in the area of resorption (Figure 7). A new treatment plan was decided on that included decoronation of the maxillary right central incisor followed by prosthetic treatment using the patient's own tooth to restore aesthetics until the patient's developmental growth was complete, after which an implantsupported porcelain crown would be provided. The surgical procedure and risks were explained to the parents, and the decoronation procedure was performed following removal of the root-canal filling (Figure 8a, b). A fixed appliance similar to the one described above for Case 1 was provided 15 days later (Figure 8c). Both the patients and the parents were 
given hygiene instructions, and follow-up examinations were scheduled at 3-month intervals. The patient was able to use the appliance without discomfort and was highly motivated by the aesthetic results and improved biting.
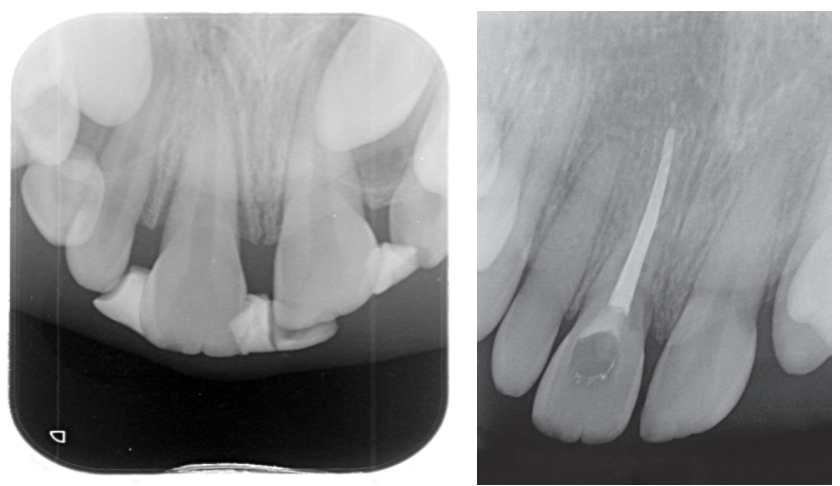

Figure 5: Initial radiographic view of Case 2 .

Figure 6: 6 months later external root resorption and ankylosis of Case 2.

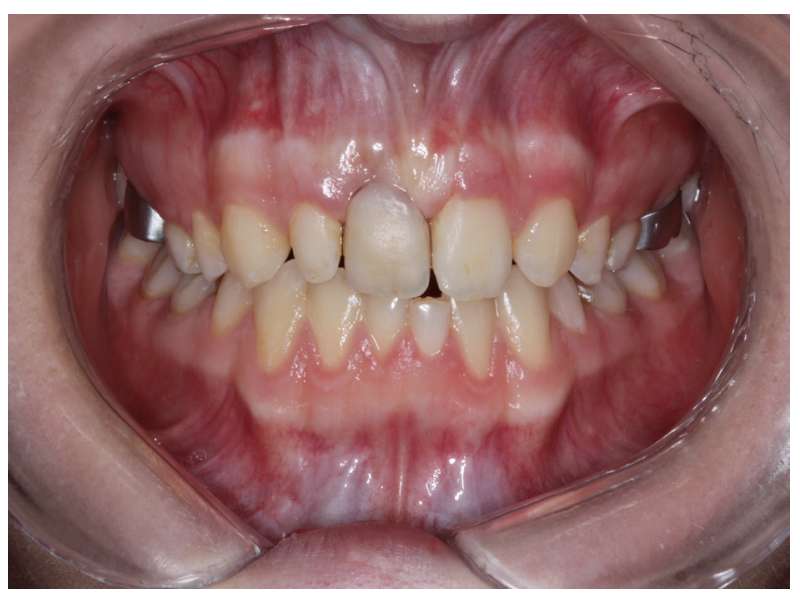

Figure 7: The radiograph of Case 2 shows horizontal root fracture, after additional traumatic injury.

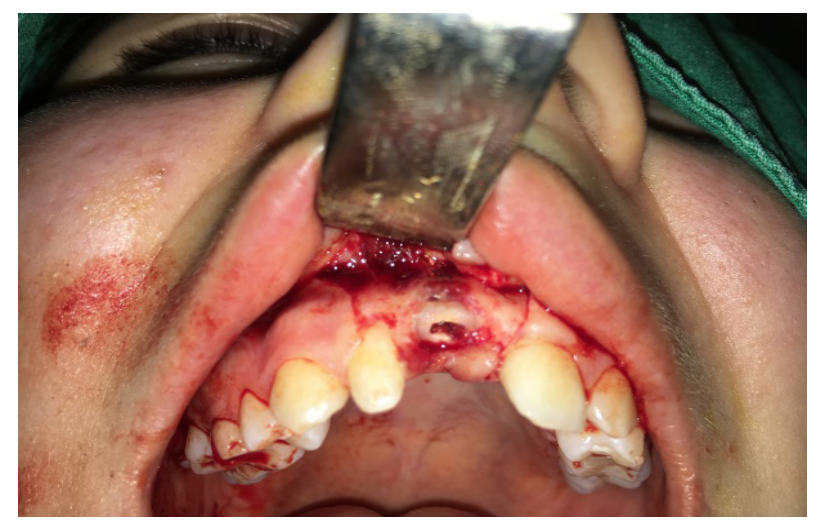

Figure 8a: Operation view

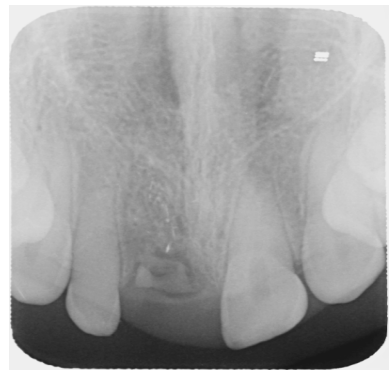

Figure 8b: Immediate radiographic view after decoronation procedure

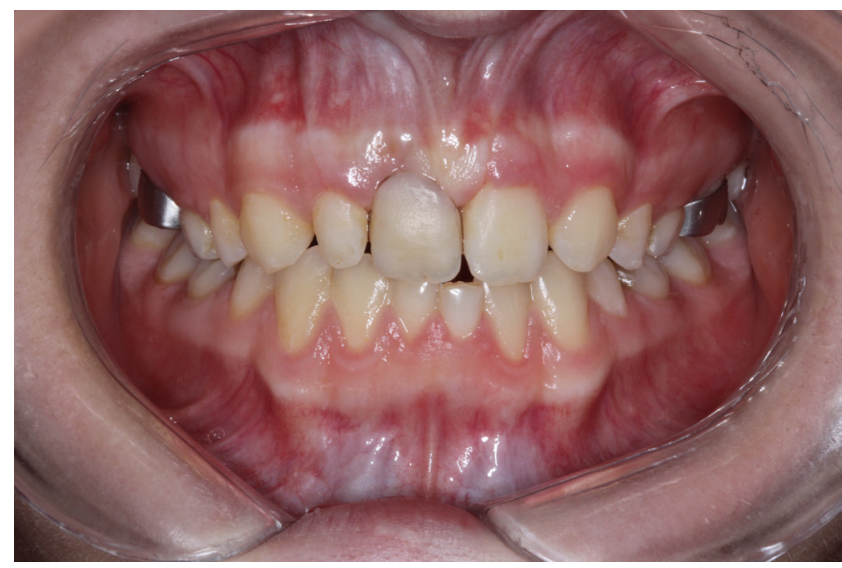

Figure 8c: Prosthetic rehabilition of Case 2

\section{Discussion}

Ideal treatment of an avulsed permanent tooth involves its immediate replantation in the socket; however, for the majority of avulsed teeth, this is not achieved. With delayed replantation, the long-term prognosis is poor, as the periodontal ligament becomes necrotic and is not expected to heal $(2-4,6)$, and the chance of external resorption for teeth that have been out of the mouth for more than 2 hours is reportedly $95 \%$ (11). In spite of the poor prognosis for these teeth, replantation is performed for aesthetic, functional and psychological reasons and to maintain the alveolar bone contour $(2,7)$. In both cases described here, delayed replantation was expected to result in ankylosis and external resorption, which were observed at 24 months in Case 1 and at 15 months in Case 2.

When deciding among treatment options for ankylosed teeth in young patients, the factors to be considered include the age of the child, the vertical discrepancy between the ankylosed and adjacent teeth, growth patterns and other minor variables, future orthodontic or prosthetic treatment, 
space maintenance, aesthetics, eruption status of adjacent teeth, behaviour management, risk of caries, and treatment $\operatorname{cost}(7,8,10,12)$. Treatment modalities include early extraction of the ankylotic tooth, extraction followed by orthodontic space-closure, auto-transplantation, singletooth dento-osseous osteotomy, intentional replantation, and decoronation (2,8,9,12-15). Immediate extraction of ankylotic teeth is not routinely recommended because early extraction can lead to alveolar bone damage (8). Orthodontic space-closure following early loss of a traumatized tooth offers an aesthetic solution as well as rehabilitation of the alveolar bone ridge;(14) however, underlying malocclusions, dental and skeletal age as well as tooth shape and size need to be taken into consideration when weighing the costs and benefits of this type of treatment (7) Auto-transplantation of a premolar, preferably using a first mandibular premolar, offers a long-lasting physiological and aesthetic solution that is recommended when the premolar root has completed less than three-quarters of its development and is considered an appropriate option for younger patients $(9,15)$ For adult patients, a single-tooth dento-osseous osteotomy, which involves the transposition of bone to move the ankylosed tooth to a more coronal position, is preferred (13).

In the cases reported on here, decoronation followed by prosthetic rehabilitation was chosen as the most appropriate treatment modality because of the patients' young ages and the lower cost and faster treatment time in relation to the other treatment options. In addition, in Case 2, the patient had a peg-shaped adjacent lateral incisor and congenital tooth abnormalities that made orthodontic treatment, autotransplantation and implant treatment complicated.

Decoronation of ankylotic teeth is recommended especially to preserve the contour of the alveolar ridge (7,10,16-19). According to Oikarinen et al.'s review of the most recent literature on the procedures and materials used in rebuilding a narrow anterior alveolar ridge, an ankylotic tooth that is well-aligned in the bony arch does not usually require ridge augmentation following decoronation (19). Disadvantages of decoronation include the need for a longterm aesthetic space maintainer as well as the surgical nature of the procedure, which may be challenging with young children (18).

The replacement of a lost crown in young patients in mixed dentition can be complicated. The available treatment options include placement of the natural crown or acrylic tooth in a fixed or removable prosthesis, fiber-reinforced composite, implants, substitution of laterals and canines, and conventional and adhesive bridges (20-25). There are some disadvantages associated with removable prostheses, such as a lack of stability, unfavourable distribution of stress, tissue inflammation and the need for patient compliance. A conventional bridge requires preparation of healthy abutment teeth for crowns. Maryland bridges are preferred in growing children; however, when used to restore a missing tooth, clinical and laboratory procedures take up extensive time, including preparation of a slot in abutment teeth to receive the retentive extensions of the wings of the pontic (22) and debonding of the cast-metal framework (23). In contrast to Maryland bridges, fiberreinforced composite (FRC) bridges require very little or no tooth reduction and offer enhanced aesthetics (21) without complicated laboratory procedures (23). Despite these advantages, in the cases presented here, FRC bridges could not be used due to the small size of the adjacent teeth. After discussing all available treatment options with the parents and children, construction of fixed appliances using the patients' natural crowns was agreed in both cases.

Successful management of ankylosed teeth requires an interdisciplinary approach. Decoronation makes it possible to maintain alveolar bone ridge width, height and continuity in order to support future rehabilitation. Maintaining the width of the alveolar ridge allows for optimal positioning of an implant and ideal aesthetic shaping of the crown. The cases reported on here highlight decoronation as an appropriate treatment option for ankylosed permanent teeth.

\section{References}

1. Glendor U, Hailing A, Andersson L, Eilert - Petersson E. Incidence of traumatic tooth injuries in children and adolescents in the county of Vastmanland, Sweden. Swed Dent J 1996; 20:15-28.

2. Andersson L, Andreasen JO, Day P, Heithersay G, Trope M, Diangelis AJ, Kenny DJ, Sigurdsson A, Bourguignon C, Flores MT, Hicks ML, Lenzi AR, Malmgren B, Moule AJ, Tsukiboshi M. International Association of Dental Traumatology. International Association of Dental Traumatology guidelines for the management of traumatic dental injuries: 2. Avulsion of permanent teeth. Dent Traumatol 2012; 28:88-96.

3. Andreasen J.O. and Andreasen F.M. Textbook and Color Atlas of Traumatic Injuries to the Teeth. Ed. Copenhagen, Denmark. 2007;444-480.

4. Andreasen JO, Borum MK, Jacobsen HL, Andreasen FM. Replantation of 400 avulsed permanent incisors. Factors related to periodontal ligament healing. Endod Dent Traumatol 1995; 11:76-89, 
5. Kinirons MJ, Boyd DH, Gregg TA. Inflammatory and replacement resorption in reimplanted permanent incisors teeth: a study of the characteristics of 84 teeth. Endod Dent Traumatol 1999;15:269-272.

6. Donaldson M, Kinirons MJ. Factors affecting the time of onset of resorption in avulsed and replanted incisor teeth inchildren. DentTraumatol 2001;17:205-209.

7. Andreasen JO, Malmgren B, Bakland L. Tooth avulsion in children: to replant or not. Endod Topics 2006;14: 28-34.

8. Malmgren B. Decoronation: how, why and when?. J Calif Dent Assoc 2000; 28:846-854.

9. Andreasen JO, Andreasen FM. Textbook and Color Atlas of Traumatic Injuries to the Teeth Ed. Copenhagen, Denmark 2007;40-760.

10. Malmgren B, Cvek M, Lundberg M, Frykholm A. Surgical treatment of ankylosed and infrapositioned reimplanted incisors in adolescents. Scand J Dent Res 1984;92:391-399.

11. Andreasen JO. Effect of extra-alveolar period and storage media upon periodontal and pulpal healing after replantation of mature permanent incisors in monkeys. Int JOral Surg 1981;10:43-53.

12. Filippi A, Pohl Y, von Arx T. Treatment of replacement resorption with Emdogain - preliminary results after 10 months. Dent Traumatol 2001;17:134-138.

13. Medeiros PJ, Bezerra AR. Treatment of an ankylosed incisor by single tooth dento-osseous osteotomy. Am J Orthod Dentofacial Orthop 1997; 112:496-501.

14. Sabri R. Treatment of a class I crowded malocclusion with an ankylosed maxillary central incisor. Am J Orthod Dentofacial Orthop 2002;122:557-565.

15. Andreasen JO, Paulsen HU, Yu Z, Schwartz O. A longterm study of 370 autotransplanted premolars. Part III. Periodontal healing subsequent to transplantation. Eur $\mathrm{J}$ Orthod 1990;12:25-37.
16. Malmgren B, Tsilingaridis G, Malmgren O. Long-term follow up of 103 ankylosed permanent incisors surgically treated with decoronation - a retrospective cohort study. Dent Traumatol 2015;31:184-189.

17. Díaz JA, Sandoval HP, Pineda PI, Junod PA. Conservative treatment of an ankylosed tooth after delayed replantation: a case report. Dent Traumatol 2007;23:313-317.

18. Sapir S, Kalter A, Sapir MR. Decoronation of an ankylosed permanent incisor: alveolar ridge preservation and rehabilitation by an implant supported porcelain crown. Dent Traumatol 2009;25:346-349.

19. Oikarinen KS, Sandor GKB, Kainulainen VT, Salopen Kemppi M. Augmentation of the narrow traumatized anterior alveolar ridge to facilitate dental implant placement. Dent Traumatol 2003;19:19-29.

20. Ulusoy AT, Cehreli ZC. Provisional use of a natural tooth crown following failure of replantation: A case report. Dent Traumatol 2008;24:96-99.

21. Tuzuner T, Kusgoz A, Nur BG. Temporary management of permanent central incisors loss caused by trauma in primary dentition with natural crowns: A case report. Dent Traumatol 2009;25:522-526.

22. Parker RM. An ultraconservative technique for restoring a missing central incisor. Contemp Esthetics 2007;7:30-34.

23. Aydin Y, Kargul B. Glass-Fiber Reinforced Composite in Management of Avulsed Central Incisor: A Case Report. J Dent Child 2004;71:66-68.

24. Ticheler HM, Abraham JE. Management of a congenitally missing maxillary cantral incisor.A case study. N Y State Dent J 2007;73:20-22.

25. Kokich VG, Crabill KE. Managing the patient with missing or malformed maxillary central incisors. Am J Orthod Dentofacial Orthop 2006;129:55-63. 